\title{
РОЛЬ СОЦІАЛЬНИХ МЕРЕЖ У ДИСТАНЦІЙНІЙ ОСВІТІ ЛІКАРІВ НА ПІСЛЯДИПЛОМНОМУ ЕТАПІ
}

\author{
М. Ю. Колесник, І. С. Качан \\ Запорізький державний медичний університет

\begin{abstract}
ROLE OF SOCIAL NETWORKS IN DOCTORS' DISTANT POST-GRADUATE EDUCATION
\end{abstract} \\ M. Yu. Kolesnyk, I. S. Kachan \\ Zaporizhian State Medical University
}

\begin{abstract}
Стаття висвітлює досвід використання соціальних мереж як інтерактивної платформи для дистанційного навчання лікарів-інтернів та випускників кафедри сімейної медицини, терапії та кардіології факультету післядипломної освіти Запорізького державного медичного університету. Описано структуру та принципи функціонування створених сторінок у мережах “Facebook” i “ВКонтакте”, основні форми та засоби навчання, шляхи інтерактивної взаємодії, переваги цього варіанта дистанційної освіти за фахом “Загальна практика - сімейна медицина” i “Внутрішні хвороби” над іншими на післядипломному етапі.
\end{abstract}

The article presents the experience of social networks using as an interactive platform for training of interns and post-graduates of the Family Medicine, Therapy and Cardiology Department of Zaporizhian State Medical University. The description includes the structure and principles of functioning of created pages in "Facebook" and "VKontakte", the basic forms and methods of teaching, ways of interactivity, the advantages of this option of distance education in the specialty "General practice - Family medicine" and "Internal medicine" above the other methods of post-graduate stage.

Вступ. Незважаючи на провідне значення практичної підготовки безпосередньо біля ліжка хворого і на робочому місці протягом інтернатури, сьогодні дистанційна форма навчання є однією 3 найперспективніших та ефективних як на до-, так і на післядипломному етапі [1]. Згідно з наказом Міністерства освіти і науки (МОН) України від 25.04.2013 р. № 466, під дистанційним навчанням розуміють індивідуалізований процес набуття знань, умінь, навичок і способів пізнавальної діяльності людини, який відбувається в основному за опосередкованої взаємодії віддалених один від одного учасників навчального процесу в спеціалізованому середовищі, яке функціонує на базі сучасних психолого-педагогічних та інформаційно-комунікаційних технологій [2]. Нормативно-правова база дистанційного навчання включає також Закон України “Про вищу освіту" від 01.07.2014 р. № 1556-VII, наказ МОН України “Про затвердження Вимог до вищих навчальних закладів та закладів післядипломної освіти, наукових, освітньо-наукових установ, що надають освітні послуги за дистанційною формою навчання

(с) М. Ю. Колесник, І. С. Качан з підготовки та підвищення кваліфікації фахівців за акредитованими напрямами і спеціальностями” від 30.10.2013 р. № 1518. На сьогодні розробка, впровадження, оцінка ефективності та вдосконалення технологій дистанційної освіти є актуальними проблемами вищої школи.

Основна частина. Основними традиційними видами навчальних занять за дистанційною формою навчання є: лекція, семінар, урок, практичні заняття, лабораторні заняття, консультації та інші [2]. Колективи кафедр Запорізького державного медичного університету за підтримки ректорату в 2015-2016 навчальному році почали розробляти та впроваджувати он-лайн-курси на платформі “EdX”, яка дозволяє поєднати декілька форм дистанційного навчання і контролю знань та навичок студентів і лікарів-інтернів. На сьогодні більшість дисциплін додипломного етапу освіти включає розділи, які студенти опановують поза стінами навчальних підрозділів. На початку 2015-2016 навчального року співробітники кафедр під керівництвом викладачів медичної інформатики, методичних рад факультетів та центральної методичної комісії університету розробили положення про дистанційні курси та 
критерії їх якості. При цьому підготовку та впровадження даних форм і засобів у навчальний процес визнано одними з основних показників роботи кафедр, що знайшло відображення у критеріях рейтингової оцінки діяльності викладачів.

Необхідно зазначити, що організація навчального процесу в інтернатурі має певні відмінності від системи освіти студентів. Тому співробітники кафедри сімейної медицини, терапії та кардіології факультету післядипломної освіти в процесі освоєння методики викладання в дистанційній формі зіткнулися з низкою проблем. Так, якщо використання інформаційних технологій при підвищенні кваліфікації практичних лікарів без відриву від виробництва на циклах тематичного вдосконалення є виправданим та логічним, то проведення он-лайн-курсів за програмою з лікарями-інтернами не має безперечних переваг над навчанням на клінічній базі кафедри під керівництвом викладача. Це пов'язано з двома чинниками: по-перше, метою інтернатури є підготовка до практичної роботи, тому опанування та вдосконалення знань і навичок повинні відбуватися без відриву від пацієнтів та конкретних клінічних ситуацій, по-друге, час аудиторного навчання займає весь робочий день, тому немає можливості та сенсу поєднувати дистанційне навчання за програмою з навантаженням у клініці. Крім того, складним виявився вибір тематики он-лайн-курсів, адже освоєння тем очного періоду згідно з робочою програмою відбувається на кафедрі з використанням класичних методик та засобів навчання. 3 урахуванням наведених вище факторів та з огляду на те, що дистанційне навчання має оптимізувати підготовку лікаря, а не ускладнювати її, на кафедрі було прийнято рішення адаптувати форму он-лайннавчання під вимоги та реалії післядипломного етапу освіти за фахом "Загальна практика - сімейна медицина” та "Внутрішні хвороби”.

Для реалізації цієї мети як інтерактивну платформу обрано соціальні мережі. Вибір саме цього варіанта грунтується на декількох положеннях. Поперше, можливість охоплення аудиторії та організації професійного спілкування без застосування додаткових програм і обладнання. По-друге, середній час активного перебування користувачів у соціальних мережах на сьогодні становить майже дві години, що дає змогу ефективно поєднувати дозвілля та підготовку поза навчальною аудиторією [3]. По-третє, стандартний функціонал соціальних мереж відповідає більшості вимог до ефективної співпраці викладача та контингенту осіб, які на- вчаються [4]. Тому на початку вересня 2016 р. ми створили групи кафедри в мережах "Facebook" та "ВКонтакте”, які є найпопулярнішими в Україні [5].

Контент інформаційної частини спілки включає фото викладачів, цікавих моментів навчального процесу, основні дані про склад, напрямки роботи кафедри, контактні дані (адреса, номери телефонів, електронна пошта), а також посилання на електронні ресурси на порталі університету, матеріали, що зберігаються в електронному архіві бібліотеки, та сторінку кафедри на офіційному сайті університету.

У розділі “Документи” наведено розклад занять і циклів для лікарів-інтернів, інформацію про лікувальну та наукову роботу кафедри. Крім того, постійно поповнюється та оновлюється база настанов, наказів і статей, які можуть стати в нагоді в процесі роботи в групі. Розділ “Обговорення” призначений для збору думок та дискусії з окремих важливих аспектів практичної діяльності лікарів. Відеоматеріали, які використовуються 3 навчальною метою, також зберігаються у відповідному розділі, що поліпшує їх систематизацію.

Основним робочим простором на сторінці кафедри $є$ так звана стіна, яка являє собою “живий” перелік подій групи, який послідовно оновлюється, відображаючи організаційну структуру етапів діяльності учасників. При цьому свіжі матеріали публікуються вище та постають для огляду в першу чергу.

У процесі роботи використовуються такі форми та засоби навчання:

- клінічні випадки з їх розбором;

- опитування та голосування;

- клінічні та навчальні дискусії;

- повідомлення про актуальні новини за напрямками професійної діяльності;

- обговорення аспектів імплементації настанов та протоколів у практику, аналіз;

- творче моделювання клінічних ситуацій на основі прикладів 3 художньої літератури та інших видів мистецтва.

Інтерес до такої форми інтерактивного навчання підкреслюється тим, що запити на приєднання до групи в соціальних мережах почали надсилати випускники кафедри минулих років. Більшість 3 них склали лікарі, які закінчили інтернатуру протягом останніх двох-трьох років. На нашу думку, цей контингент потребує окремої уваги. Початок самостійної практики після тривалого навчання в університеті завжди супроводжується значним психоемоційним навантаженням. Нерідко молоді лікарі за фахом “Загальна практика - сімейна ме- 
дицина” працюють в умовах, коли поруч 3 ними відсутні досвідчені лікарі зі стажем, до яких можна звернутися за допомогою та порадою. Професійне спілкування в соціальних мережах може бути певною альтернативою для таких спеціалістів. Вони мають безпосередню можливість обговорити клінічні ситуації з власної практики зі своїми колишніми викладачами. Функціонал соціальних мереж дозволяє лікарям-інтернам самим створювати теми для обговорення, ставати ініціаторами нових дискусій. Безперечно, модератори групи (викладачі) повинні контролювати дотримання захисту персональних даних пацієнтів та відповідність дискусії принципам медичної етики і деонтології.

Клінічні випадки виносяться на розгляд у формі наочних міні-фільмів на основі мультимедійних презентацій, відображаючи поточну лікувальнодіагностичну роботу клініки, що дозволяє лікарямінтернам зануритися в ситуацію глибше, уточнити окремі нюанси не тільки дистанційно, відкрито спілкуючись із модератором, але й під час проходження циклів на кафедрі. До того ж, перевагою такої форми розгляду проблеми є одночасна участь майже всіх осіб, які навчаються та викладають на кафедрі, що дає можливість оперативно виправляти недоліки в методиці, покладаючись на конструктивну критику колег, лікарів-інтернів та випускників кафедри, які мають досвід практичної роботи.

Принцип інтерактивності реалізується після інформування учасників про подію шляхом можливості коментування, організації колективних чатів, голосування та активного опитування. Необхідно зазначити, що анкетування та збір думок учасників проводяться з можливістю анонімної відповіді (за допомогою он-лайн-форм), що підвищує ефективність включення в обговорення більшості лікарівінтернів. При цьому анонімні дані залишаються доступними для широкої аудиторії, тому підтримують подальшу дискусію.

Розбір клінічної ситуації починається з висловлювання думок учасників стосовно попереднього діагнозу та відповідей на їх запитання, які уточнюють деталі скарг, анамнезу, об’єктивних ознак і даних додаткових досліджень. На наступному етапі модератор, не відкриваючи правильної відповіді, намагається наштовхнути на подальший пошук тих, хто запропонував неправильний діагностичний або лікувальний напрямок. Для цього відкрито аналізуються чинники “за” та “проти” для неправильних версій за принципом проведення диференційної діагностики. За необхідності інформація доповню- ється даними про пацієнта, які були приховані на початку, з метою наближення віртуальної ситуації до реалій практичної послідовної роботи лікаря. На заключному етапі, поряд з обгрунтуванням діагнозу та визначенням “переможців”, модератор клінічного випадку завершує розбір ілюстрованим інформаційним фрагментом, висвітлюючи сучасні підходи до діагностики та лікування згідно з рекомендаціями, настановами і протоколами.

Однією з переваг використання соціальних мереж в організації навчального процесу також є можливість отримання актуальної інформації про освітні потреби лікарів. Навчальна програма з інтернатури за фахом “Загальна практика - сімейна медицина” та “Внутрішні хвороби” передбачає варіативну частину, яку кожна кафедра формує, виходячи 3 можливостей і традицій клінічної бази. Теми лекцій та семінарів варіативної частини викладачі найчастіше пропонують без обговорення з інтернами. У 2016-2017 навчальному році на сторінці кафедри в соціальній мережі проведено рейтингове опитування, в якому інтернам було запропоновано обрати найбільш цікаву для них тему лекції серед кількох варіантів. Такі голосування дозволяють зрозуміти, яким розділам знань потрібно приділити більше уваги, які теми залишилися без обговорення під час навчання на попередніх профільних кафедрах.

На сьогодні контент нашої групи формується за графіком із збереженням співвідношення різних форм навчання: один раз на тиждень - клінічний випадок, опитування або голосування, 2-3 рази на тиждень - інформування про актуальні медичні новини в межах навчальних дисциплін, постійно за необхідності - внесення змін до організаційноінформаційної частини про розклад, події, конференції тощо. При цьому свіжі матеріали публікуються вище та постають для огляду в першу чергу.

Ще однією формою роботи, що використовується на сторінці нашої кафедри в соціальних мережах “Facebook” та "ВКонтакте”, є створення навчальних відеофільмів. Під час опанування практичних навичок лікарям-інтернам пропонується скласти сценарій та після погодження 3 викладачем відзняти невеликий відеоролик, який буде відображати основні методологічні принципи проведення стандартних діагностичних процедур (наприклад, спірографії, електрокардіографії). При цьому створені фільми стають доступними для широкого кола освітньої спільноти. Така підтримка та визнання підвищують мотивацію в інших до участі в підготовці навчальних матеріалів. 
Висновки. Таким чином, однією з форм дистанційного навчання в інтернатурі за фахом “Загальна практика - сімейна медицина” та "Внутрішні хвороби” можуть бути освітні сторінки профільної кафедри. Функціональні можливості соціальних

\section{Список літератури}

1. Кравчук I. В. Впровадження дистанційних технологій навчання в медицину та систему медичної освіти / I. В. Кравчук // Зб. наук. праць співробіт. НМАПО імені П. Л. Шупика. - 2015. - № 24 (1). - С. 615-627.

2. Про затвердження Положення про дистанційне навчання : наказ Міністерства освіти і науки України від 27.06.2013 p. № 466.

3. Statistics and Market Data on Social Media \& UserGenerated Content [Електронний ресурс]. - Режим доступу: https://www.statista.com/markets/424/topic/540/ social-media-user-generated-content/ мереж дозволяють оптимізувати та урізноманітнити навчальний процес на післядипломному рівні, підвищуючи престиж кафедри й ефективність співробітництва лікарів-інтернів та викладачів.

4. Peter Cartledge. The use of social-networking sites in medical education / Peter Cartledge, Michael Miller, Bob Phillips // Medical Teacher. - 2013. - Vol. 35. [Електронний ресурс]. - Режим доступу: http://dx.doi.org/10.310 9/0142159Х.2013.804909.

5. Дідик Л. А. Інтернет-комунікації vs соціальні мережі: причини “popularization” / Л. А. Дідик // Зб. наук. праць “Міжнародний науковий форум: соціологія, психологія, педагогіка, менеджмент”. - 2013. - № 14. С. 84-93. 